\title{
First report of johnsongrass mosaic virus in Argentina
}

\author{
V. Trucco ${ }^{1,2} \cdot$ D. Cabrera Mederos ${ }^{1,2} \cdot$ S. Lenardon ${ }^{1,3} \cdot$ F. Giolitti ${ }^{1,2}$ (i) \\ Received: 3 July 2019 / Accepted: 10 October 2019 / Published online: 21 November 2019 \\ (C) Australasian Plant Pathology Society Inc. 2019
}

\begin{abstract}
Potyviruses are responsible for important economic losses in maize crop. This work reports the detection of johnsongrass mosaic virus, a potyvirus affecting maize in Argentina. Electron microscopy studies, mechanical transmission tests and molecular assays based on the CP gene were performed. To our knowledge, this is the first detection of JGMV in Argentina.
\end{abstract}

Keywords Zea mays L. P Potyvirus · Johnsongrass mosaic virus $\cdot$ Symptomatology $\cdot$ Mechanical transmission $\cdot$ CP sequence $\cdot$ Phylogenetic analysis

Maize (Zea mays) is one of the most important cereal crops in Argentina. The country ranks fifth in maize production and third in exports in the world (USDA 2018). The cultivated area in Argentina exceeds 6 million hectares, producing over 40 million tons ('Bolsa de Cereales' 2019). In Córdoba province, the cultivated area was over 2.2 million hectares in $2017 / 18$, with a production of above 11 million tons (BCCBA 2019). This crop can be affected by multiple viruses of several taxonomic groups worldwide, including members of the family Potyviridae. Specific potyviruses, such as maize dwarf mosaic virus (MDMV), sugarcane mosaic virus (SCMV), wheat streak mosaic virus (WSMV), and johnsongrass mosaic virus (JGMV), were shown to cause the devastating maize lethal necrosis disease (MLN) in synergistic coinfection with maize chlorotic mottle virus (MCMV), a virus belonging to the genus Machlomovirus of family

Electronic supplementary material The online version of this article (https://doi.org/10.1007/s13314-019-0365-2) contains supplementary material, which is available to authorized users.

F. Giolitti

giolitti.fabian@inta.gob.ar

1 Instituto Nacional de Tecnología Agropecuaria, Centro de Investigaciones Agropecuarias, Instituto de Patología Vegetal (INTA-CIAP-IPAVE), Av. 11 de septiembre 4755, X5020ICA Córdoba, Argentina

2 Consejo Nacional de Investigaciones Científicas y Técnicas, Unidad de Fitopatología y Modelización Agrícola (CONICET-UFyMA), Av. 11 de Septiembre 4755, X5020ICA Córdoba, Argentina

3 Facultad de Agronomía y Veterinaria (FAV), Universidad Nacional de Río Cuarto (UNRC), Enlaces Rutas 8 y 36, 5800, Río Cuarto, Córdoba, Argentina
Tombusviridae (Redinbaugh and Stewart 2018; Stewart et al. 2017). In Argentina, earlier studies revealed the presence of MDMV, SCMV, WSMV and MCMV, as well as their synergistic interaction, causing MLN to maize crop (Giménez Pecci and Laguna 2012; Giménez Pecci et al. 2017). The present work aimed to determine the presence of JGMV in maize samples collected in Córdoba province, Argentina.

JGMV was first reported in Australia as maize dwarf mosaic virus (MDMV) (Taylor and Pares 1968), and subsequently detected in several countries, including Brazil, Colombia, Nigeria, USA and Venezuela (Garrido and Trujillo 1993; McDaniel and Gordon 1989; Morales et al. 1996; Seifers et al. 2005; Silva et al. 2013). JGMV infection causes mosaic and chlorotic vein symptoms in several monocotyledonous species. The virus is spread by some aphid species in a nonpersistent manner; and can also be mechanically transmitted, but not through seed (Shukla and Teakle 1989).

Maize plants showing symptoms associated with viral infection were collected in the northern area of Córdoba province, in the localities of Jesús María, Pozo del Tigre and Villa del Totoral in 2004. Symptomatic leaf samples were lyophilized and stored for future analysis. The affected plants showed leaf symptoms of mosaic with fine chlorotic streaks and ringspots (Fig. 1a). Healthy maize plants were mechanically inoculated using sap from symptomatic leaves extracted with phosphate buffer $\left(0.01 \quad \mathrm{M} \mathrm{Na}_{2} \mathrm{HPO}_{4} / \mathrm{NaH}_{2} \mathrm{PO}_{4}, \mathrm{pH} 7+0.1 \%\right.$ $\mathrm{Na}_{2} \mathrm{SO}_{3}$ ) and 600-mesh silicon carbide as abrasive; the inoculated plants produced similar symptoms 15 days after inoculation (Fig. 1b). Electron microscopy observations of leaf-dip preparations revealed the presence of typical flexuous-filamentous potyvirus particles $\sim 750 \mathrm{~nm}$ long and $\sim 12 \mathrm{~nm}$ wide (Fig. 1c). 
Fig. 1 Symptoms of JGMV-Arg isolate in maize (Zea mays) collected from the field in Córdoba province (a) and induced by mechanical inoculation in healthy maize plants (b). Leaf-dip preparation form symptomatic maize samples showing flexuousfilamentous particles typical of potyviruses (c)

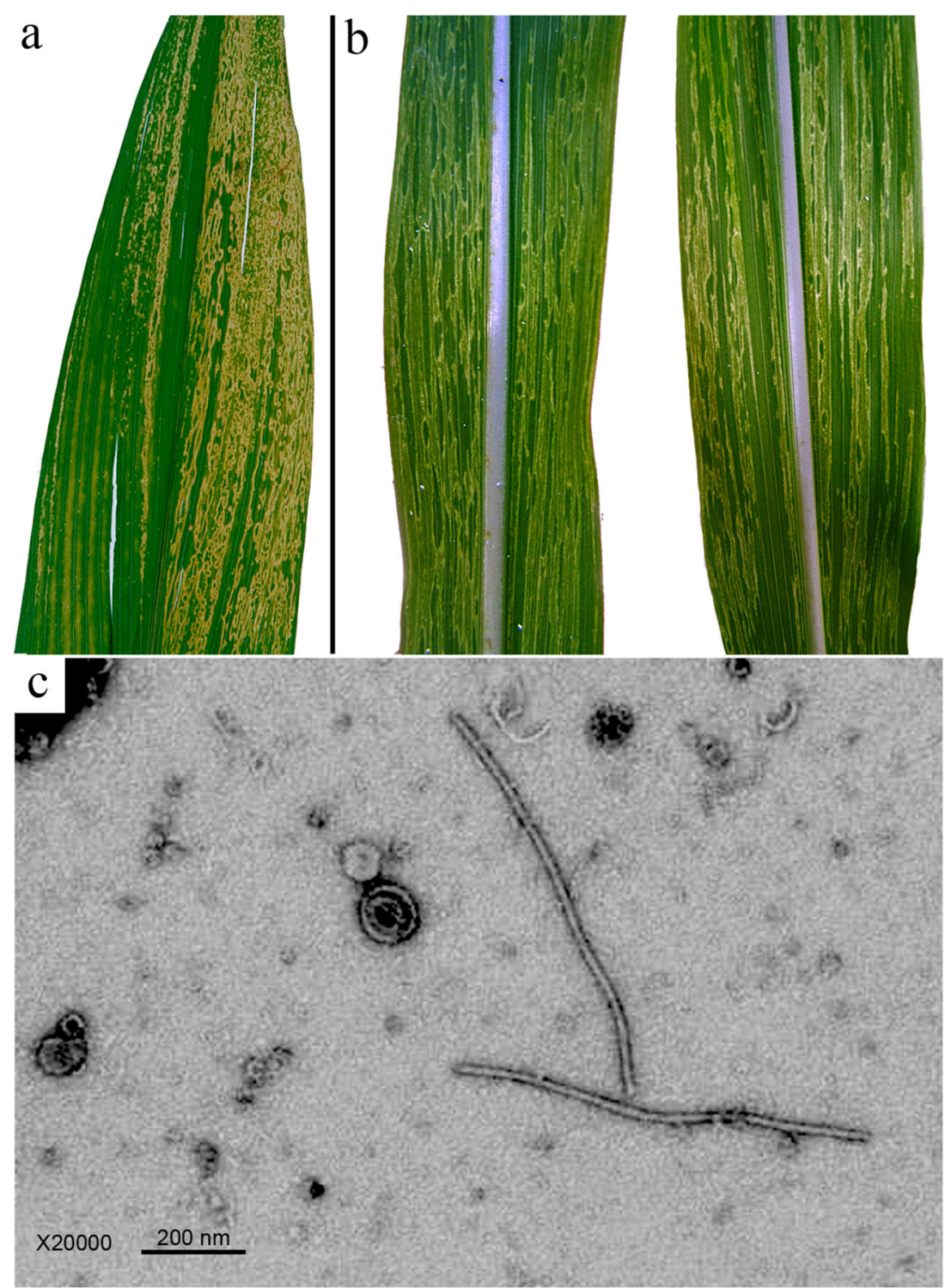

The leaf samples were serologically tested by DAS-ELISA against JGMV, MDMV, sorghum mosaic virus (SrMV) and SCMV using commercial antisera (Loewe Biochemica $\mathrm{GmbH}$, Germany), and retested with our antisera against Argentine isolates of MDMV and SCMV (IPAVE-CIAPINTA). The samples reacted positively only with JGMV antisera, although with weak colour development (absorbance values about 0.18 , with a cut-off value of 0.08 and a positive control of 1.11). Total RNA was extracted using Trizol reagent (Invitrogen, CA, USA). Reverse transcriptions followed by PCRs were carried out using MMLV reverse transcriptase (Promega, Madison, WI, USA), KAPA HiFi HotStart DNA polymerase (KAPA Biosystems, USA), and the primers JGMV-F (5'-AGAGATGTACAAGAACGCCATCGC-3') and JGMV-R (5'-CATCCTTTAACGTCAGATAGACGG$3^{\prime}$ ), designed to amplify a $\sim 1000$-bp fragment of the coat protein $(\mathrm{CP})$ gene of JGMV. The RT-PCR products, obtained in triplicate from symptomatic plants, were purified using the Wizard SV Gel and PCR Clean-Up System (Promega) and sequenced in both directions (Macrogen, South Korea). The obtained sequences were assembled into the final consensus sequence (906 nucleotides) using Staden Package program v 2.0.0b10 (available at http://staden.sourceforge.net/) and ORF finder tool (https://www.ncbi.nlm.nih.gov/orffinder/). BLAST analysis of the obtained sequence confirmed the identification of JGMV. The complete nucleotide (nt) sequence of the CP gene of the Argentine JGMV isolate (JGMV-Arg) was deposited in GenBank under accession number MK411416.

Pairwise identity analyses between the JGMV-Arg sequence and those available in GenBank from Australia, Brazil, Ethiopia, Kenya, Nigeria and USA were carried out using the MUSCLE-based pairwise alignment option implemented in SDT v1.2 (Muhire et al. 2014). The percentages of nucleotide sequence identities ranged from $76.0 \%$ to $98.2 \%$, 
Fig. 2 Phylogenetic relationship (neighbour-joining method) based on the CP amino acid sequence of the Argentine JGMV isolate (indicated with an asterisk) with other 32 JGMV isolates from Australia, Brazil, Ethiopia, Kenya, Nigeria and USA. The scale bar indicates pairwise nucleotide distance. Bootstrap values are shown as percentages of 1000 replications (values below $50 \%$ are not shown). Origin and access number are indicated for each CP amino acid sequence

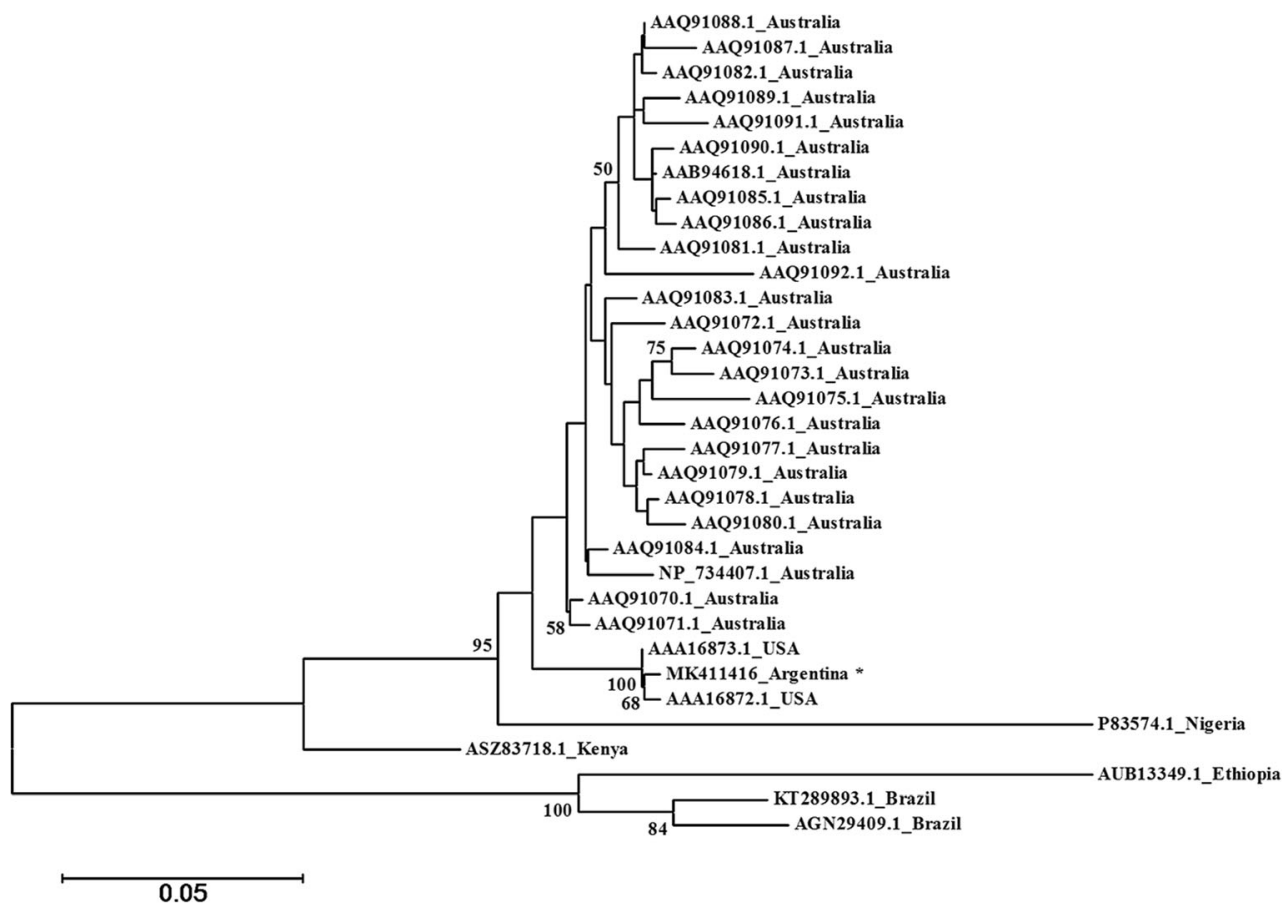

showing the lowest and highest values with the isolate from Brazil (KC333416.1) and USA (U07218.1), respectively. Comparison of CP deduced amino acid (aa) sequence revealed the lowest identity value of $77.6 \%$ with the isolate from Ethiopia (AUB13349.1) and the highest value of $99.0 \%$ with the isolate from USA (AAA16873.1), as shown in the colorcoded matrix of pairwise identity scores (Online Resource 1). These results are consistent with the Potyvirus species demarcation convention based on CP identity (Adams et al. 2005).

The neighbour-joining (NJ) and maximum-likelihood (ML) phylogenetic trees were constructed based on the full CP aa sequences using MEGA 5 (Tamura et al. 2011), with the best-fitted substitution model $(\mathrm{JTT}+\mathrm{G})$ and 1000 bootstrap replicates. The topology of the NJ (Fig. 2) and ML (data not shown) trees indicated that JGMV-Arg shared the closest evolutionary relationships with those from USA (AAA16872.1 and AAA16873.1). The phylogenetic relationships between the JGMV isolates support the results obtained by pairwise comparison (Online Resource 1).

To our knowledge, this is the first report of JGMV in Argentina. The recent detection of this virus in samples collected some years ago may be largely attributable to the high similarity of the symptoms caused by potyviruses on maize, so JGMV infection could be easily mistaken with those of the other potyviruses present in the same area where the samples were collected, such as MDMV, SCMV and WSMV (Giménez Pecci et al. 2017). Also, it might be expected that JGMV would be more widespread in the country since the aphid vectors, such as Aphis craccivora, Aphis gossypii, Myzus persicae and Rhopalosiphum maidis, are present in the country, as well as the host plants belonging to the family Poaceae, like sorghum, johnsongrass, panicum and brachiaria (Ortego et al. 2004; Shukla and Teakle 1989). Further studies are needed to understand the current situation in terms of geographical distribution, incidence/prevalence and potential contribution to MLN of this viral disease in Argentina.

Acknowledgements The present work was carried out with the support of Instituto Nacional de Tecnología Agropecuaria. The presence of JGMV in Argentina was reported to the National System for Pest Surveillance and Monitoring (Sistema Nacional Argentino de Vigilancia y Monitoreo de Plagas). We thank Nicolás Bejerman (INTA-CONICET, Argentina) for critical reading of the manuscript.

\section{Compliance with ethical standards}

Conflict of interest The authors declare that they have no conflict of interest.

Ethical approval This research does not contain any studies with human participants or animals performed by any of the authors.

\section{References}

Adams MJ, Antoniw JF, Fauquet CM (2005) Molecular criteria for genus and species discrimination within the family Potyviridae. Arch Virol 150(3):459-479

BCCBA (2019) BCCBA: Bolsa de Cereales de Córdoba. http://www. bccba.com.ar/maiz-6970.html. Accessed 29 May 2019

Bolsa de Cereales (2019) http://www.bolsadecereales.com/. Accessed 14 May 2019 
Garrido MJ, Trujillo GE (1993) Occurrence of johnsongrass mosaic virus on sorghum in Venezuela. Plant Dis 77:847

Giménez Pecci MP, Laguna IG (2012) Maize chlorotic mottle virus (MCMV) y necrosis letal del maíz. In Gimenez-Pecci MP, Laguna IG, Lenardon S (eds). Enfermedades del maiz producidas por virus y mollicutes en Argentina. Eds. INTA, pp. 91-98

Giménez Pecci MP, Maurino MF, Druetta M, Torrico AK, Oleszczuc D, Guerra FA, Guerra GD, De Rossi RL, Plazas MC, Brucher E, Barontini J, Ferrer M, Laguna IG (2017) Enfermedades del maíz de siembra tardía causadas por virus, mollicutes y bacterias. In Borras L, Uhart S (eds). El mismo maíz, un nuevo desafío, pp. $128-145$

McDaniel LL, Gordon DT (1989) Characterization of the oat-infecting strain of maize dwarf mosaic virus. Phytopathology 79:113-120

Morales FJ, Ospina MD, Castaño M, Calvert LA (1996) Sequence analysis of the genomic RNA 30-terminal region of a potyvirus from Brachiaria spp. related to Guineagrass mosaic virus. J Phytopathol 144:485-489

Muhire BM, Varsani A, Martin DP (2014) SDT : a virus classification tool based on pairwise sequence alignment and identity calculation. PLoS One 9(9):e108277. https://doi.org/10.1371/journal.pone. 0108277

Ortego J, Difabio ME, Mier Duarte MP (2004) Nuevos registros y actualización de la lista faunística de los pulgones (Hemiptera: Aphididae) de la Argentina. Revista de la Sociedad Entomológica Argentina 63:19-30
Redinbaugh MG, Stewart LR (2018) Maize lethal necrosis : an emerging, synergistic viral disease. Annual Review of Virology 5(20):1-22

Seifers DL, Haber S, Ens W, Standing KG, Salomon R (2005) Characterization of a distinct Johnsongrass mosaic virus strain isolated from sorghum in Nigeria. Arch Virol 150:557-576

Shukla DD, Teakle DS (1989) Johnsongrass mosaic virus. Description of plant viruses 340:5 http://www.dpvweb.net/dpv/showdpv.php? dpvno $=340$

Silva KN, Nicolini C, Silva MS, Fernandes CD, Nagata T, Resende RO (2013) First report of johnsongrass mosaic virus (JGMV) infecting Pennisetum purpureum in Brazil. Plant Dis 97. https://doi.org/10. 1094/PDIS-01-13-0013-PDN

Stewart LR, Willie K, Wijeratne S, Redinbaugh MG, Massawe D, Niblett CL, Kiggundu A, Asiimwe T (2017) Johnsongrass mosaic virus contributes to maize lethal necrosis in East Africa. Plant Dis 101(8): 1455-1462

Tamura K, Peterson D, Peterson N, Stecher G, Nei M, Kumar S (2011) MEGA 5: molecular evolutionary genetics analysis using maximum Likelifood, evolutionary distance, and Maximun parsimony methods. Mol Biol Evol 28:2731-2739

Taylor RH, Pares RD (1968) The relationship between sugarcane mosaic virus and mosaic viruses of maize and Johnson grass in Australia. Aust J Agric Res 19:767-773

USDA (2018) United States Department of Agriculture. In: Production, Supply and Distribution Online Data. https://apps.fas.usda.gov/ psdonline/app/index.html\#/app/downloads 